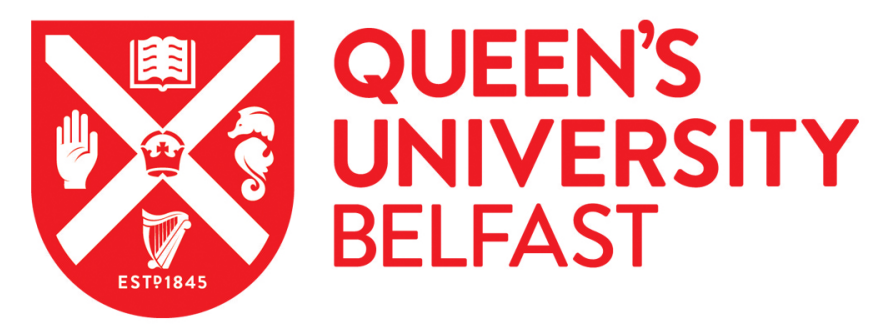

\title{
Perspectives on social citizenship in the EU - from status positivus to status socialis activus via two forms of transnational solidarity
}

Schiek, D. (2015). Perspectives on social citizenship in the EU - from status positivus to status socialis activus via two forms of transnational solidarity. Queen's University Belfast.

\section{Document Version:}

Publisher's PDF, also known as Version of record

Queen's University Belfast - Research Portal:

Link to publication record in Queen's University Belfast Research Portal

Publisher rights

@ 2015 Queen's University Belfast

\section{General rights}

Copyright for the publications made accessible via the Queen's University Belfast Research Portal is retained by the author(s) and / or other copyright owners and it is a condition of accessing these publications that users recognise and abide by the legal requirements associated with these rights.

Take down policy

The Research Portal is Queen's institutional repository that provides access to Queen's research output. Every effort has been made to ensure that content in the Research Portal does not infringe any person's rights, or applicable UK laws. If you discover content in the Research Portal that you believe breaches copyright or violates any law, please contact openaccess@qub.ac.uk. 


\section{European (Legal) Studies on-line papers}

Queen's University Belfast - School of Law - Jean Monnet ad personam Chair Professor D Schiek

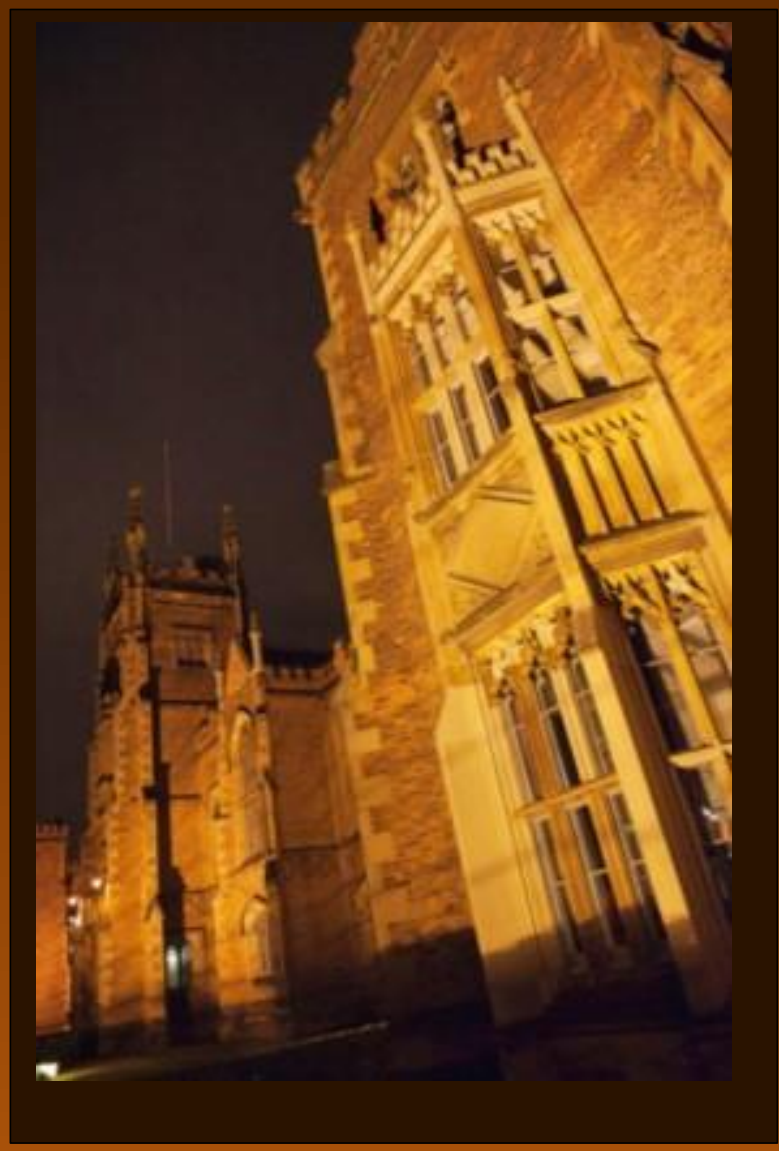

DAGMAR SCHIEK

Perspectives on social citizenship in the EU - from status positivus to status socialis activus via two forms of transnational solidarity

Volume 4, Issue 1, 2015

These on-line papers are part of the programme provided under the Jean Monnet ad Personam Chair held by Dagmar Schiek, which was part-funded by the EU Commission from September 2011 to August 2014 (University of Leeds)

This paper is the pre-print version of a book chapter, and will be published in: D. Kochenov (ed) EU Citizenship and Federalism: The Role of Rights, Cambridge University Press, in preparation - 2015 


\section{Perspectives on social citizenship in the EU - from status pos- itivus to status socialis activus via two forms of transnational solidarity}

\section{Dagmar Schiek*}

\section{A. Introduction}

Ever since the inauguration of EU citizenship, elements of social citizenship have been on the agenda of European integration. European level social benefits were proposed early on, ${ }^{1}$ and demands for collective labour rights have followed suit. ${ }^{2}$ This paper uses the theoretical umbrella of transnational social citizenship in order to link transnational access to social benefits and collective labour rights. It promotes transnational rights as the best way to conceptualise EU social citizenship as an institution enabling the enjoyment of EU integration without being forced to forego social rights at other levels. Such a perspective sits well in a collection on EU citizenship and federalism, since it simultaneously challenges demands of renationalisation of social rights in the EU and pleas to reduce EU-level citizenship rights to a merely liberal dimension. Social citizenship as promoted here requires an interactive conceptualisation of regulatory and judicial powers at different levels of government as typical for federal systems.

In linking citizenship with human rights the paper highlights different statuses of citizens. It argues that the rights constituted by social citizenship derive from a status positivus and a status socialis activus, expanding the time-honoured categories of Jellinek. ${ }^{3}$ This concept is developed further by linking the notions of receptive solidarity to the status positivus and the notion of participative solidarity to the status socialis activus. In relation to European Union citizenship it promotes a sustainable transnational social citizenship catering for receptive and participative solidarity.

These ideas contrast with most current discourses on EU citizenship. The stress on social citizenship takes issue with a retreat ${ }^{4}$ to mere liberalist notions of EU-level citizenship, and the stress on rights takes issue with conceptualising EU citizenship as a community bond with obligations, ${ }^{5}$ downplaying the empowering potential of rights. The difficulty of conceptualising transnational social citizenship is to avoid, on the one hand, taking up the tune of populist discourses imagining those moving beyond

\footnotetext{
* This paper profited from valuable suggestions by Dimitry Kochenov, which is gratefully acknowledged. The usual disclaimer applies.

1 Ph Schmitter, M W Bauer, 'A (Modest) Proposal for Expanding Social Citizenship in the EU', (2001) 11 JESP 55.

2 B Bercusson, European Labour Law, (2nd edn Cambridge: CUP, 2009), 263-65.

3 G Jellinek, System der subjektiven öffentlichen Rechte (Freiburg i. Br: Mohr, 1892), D Schiek, 'Fundamental Rights Jurisprudence between Member States' Prerogatives and Citizens' Autonomy', in H Micklitz, B de Witte (eds) The European Court of Justice and the Autonomy of Member States (Antwerp: Intersentia, 2012) 219, 221-22.

4 This retreat is a relatively recent phenomenon: in the 1990s and until the 2000s social citizenship was widely debated (see, for example L Magnusson, B Stråth (eds) A European Social Citizenship?: Preconditions for Future Policies from a Historical Perspective (Brussels: Peter Lang, 2004),Th Faist, 'Social Citizenship in the European Union: nested membership', (2001) 39 Journal of Common Market Studies, 37, and J Shaw 'The Interpretation of European Union Citizenship' (1998) 61 $M L R$ 293, 301-302. The retreat is also not ubiquitous, since adding social strands to EU citizenship is still defended (e.g. D Kostakopoulou, Co-Creating European Union Citizenship: A Policy Review (Brussels: European Commission, 2013) 47).

5 Some sociological approaches focus on this, e.g. A Hurrelmann 'Demoi-cratic Citizenship in Europe - an impossible ideal?' (2015) 22 JEPP, 19, stressing requirements citizens must fulfil to live up to the ideal of EU citizenship.
} 
state borders as a threat to national social citizenship and, on the other hand, to reject the legitimate fears of those remaining at home of creating rupture in the social fabric of Europe's society. Promoting transnational social citizenship rights based on receptive and participative solidarity the present paper aims to contribute to avoiding these pitfalls.

The paper will proceed in two parts. The first part will discuss the potential of transnational social citizenship. Linking Marshall's concept of social citizenship for the (British) nation state to concepts of welfare rights in constitutional social states, the guarantee of social rights - as opposed to voluntary hand-outs or toleration of participation - emerges as the main progress connected with social citizenship in nation states. Social, as opposed to liberal or civic citizenship, consists in the guarantee of rights to the many instead of the few, on the basis of both receptive and participative solidarity. If citizenship is defined as being connected by a shared fate of equals, it is possible to imagine transnational citizenship as a multiplicity of citizenships in overlapping and interlinking spaces. The question addressed is how a rights-based approach to social citizenship must change in order to provide transnational social citizenship in line with the two modes of solidarity-based rights. In order to illustrate its complexity, populist discourses challenging factual emanations of transnational citizenship in the EU will be used. The first part concludes that, while receptive solidarity is more difficult to adapt to transnational citizenship than participative solidarity, finding a comprehensive new mode of social citizenship rights for the transnational age is possible in principle.

The second part of the article explores the European Union as a laboratory for transnational social citizenship rights, assessing in how far its practice contributes to or hinders new modes of transnational solidarity. While EU citizenship, a legal construct severely limited by the direct reference to nationality, is certainly important here, transnational citizenship as a factual situation precedes positive law on EU citizenship. In particular, free movement rights beyond EU citizenship have engendered transnational social spaces as sites of EU social citizenship. In order to assess in how far EU law contributes or restrains transnational social citizenship in practice, ECJ case law will be analysed, using one case study for each of the two types of solidarity. As regards the status positivus, or receptive solidarity, the recent Dano case will be used as a starting point for a critical investigation into the degree to which the positive potential of non-discrimination dimension of free movement rights is realised. As regards the status socialis activus, or participatory solidarity, the analysis focuses on judicial assessment of emanations of transnational solidarity as highlighted by the Laval and Viking case law. The paper will conclude that the ECJ has a long way to go to find responsible answers to the challenges of transnational social citizenship.

\section{B. Towards transnational social citizenship}

\section{The social citizenship metaphor}

The notion of social citizenship is usually traced back to T.H. Marshall, who developed citizenship as a sociological category against the background of British politics. ${ }^{6}$ He defined citizenship as membership in a community based on equal rights, which developed alongside the rise of capitalism, a socio-economic order based on inequality. ${ }^{7}$ Wondering how these two could co-exist, T.H Marshall suggested that citizenship rights developed through a number of phases: equal civil rights of the $18^{\text {th }}$ century could easily coexist with unequal economic rights, which led to unequal political rights. However, once

\footnotetext{
6 T.H. Marshall, Citizenship and Social Class (Cambridge: Cambridge University Press, 1950).

7 Ibid 29.
} 
equal political rights had been established, some form of social citizenship had to develop in order to integrate the dispossessed classes. Thus, rights to education, healthcare, housing and to some monetary benefits replaced the factual social membership in villages and communities. While Marshall's model of a logically staged development from of first civil (liberal), then political (democratic) and then social rights was not ubiquitous in the industrialised societies of the $19^{\text {th }}$ century, ${ }^{8}$ and was written from the perspective of a non-federal national state, ${ }^{9}$ it remains relevant for establishing distinctive element of social citizenship as ideal types in any entity.

\section{Rights in constitutional welfare states}

Without using the metaphor of social citizenship, constitutionalised welfare states provide a similar answer to the necessity of affording full membership in capitalist societies through state-led endeavours aimed at social inclusion, ${ }^{10}$ offering payments for times of need on the one hand, and attachment to social institutions such as social insurance or the educational systems on the other hand. The difference between constitutionalised welfare states and social citizenship as metaphors is that the former is focused on social structures and the latter on the individual - though this is a matter of degree. ${ }^{11}$ More importantly, the constitutional social state stresses that benefits are not gracious hand-outs which may lead to inclusion, but rather rights to which a citizen has a constitutional claim, alongside claims to access social institutions. ${ }^{12}$

\section{Rights and social citizenship}

As a sociological concept, citizenship may be defined by a combination of three elements: the belonging to a community, the endowment with rights and being subjected to the corresponding obligations, ${ }^{13}$ recently summarised as a shared fate of equals. ${ }^{14}$ This kind of citizenship emerges anywhere where humans live, since humans are social animals and prone to interact and build communities and societies. When discussing EU citizenship, it is less useful to consider these timeless elements - the EU is certainly built on modernity in a particular regional variety. Here, the ascent of citizenship coincided with the ascent of the nation state, which again coincided with the demise of absolute rule by monarchs and the rise of capitalism. ${ }^{15}$ Accordingly, the community to which the new citizens belonged was

\footnotetext{
8 R Bellamy, 'Citizenship: Historical Development of', in J Whrigt (ed) International Encyclopaedia of Social and Behavioural Sciences, (Oxford: Elsevier, 2014). For example in Bismarck's Germany benefit rights were granted to appease workers while anti-socialist legislation prohibiting trade-union related rights to association were maintained D Schiek, 'Artikel 20 Abs. 1-3 V: Sozialstaat', in E. Stein, H Denninger, W Hoffmann-Riem (eds) Alternativkommentar zum Grundgesetz (Neuwied: Luchterhand, 2001), marginal number 6. Marshall conceded that the poor laws of Elizabethan Britain by granting claims to a just wage were early emanations of social citizenship, conflicting with the new civil rights supporting a competitive economy (ibid. 22).

${ }^{9}$ Accordingly, his approach requires adaptation for theorizing citizenship in a transnational federal entity such as the EU (for a critical approach to Marshall's Concepts in relation to the EU see G de Búrca, 'Report on the Further Development of Citizenship in the European Union', ZfSR (2001), 39, 50.

10 See, for example, P Taylor-Gooby, Reframing Social Citizenship (Oxford: OUP, 2008).

11 Marshall also related to institutions necessary to guarantee social citizenship (n 6) 52-59.

12 See G S Katrougalos, 'The (Dim) Perspectives of the European Social Citizenship', Jean Monnet Working Papers New York University School of Law, 5 (2007)

13 R Bellamy (n.8).

14 M R Somers, Genealogies of Citizenship: Markets, Statelessness, and the Right to Have Rights (Cambridge: CUP, 2008).

15 For a brief narrative on the birth of constitutional rights in Europe with further references see D Schiek, Economic and Social Integration. The Challenge for EU Constitutional Law (Cheltenham: Edward Elgar, 2012), pp. 54-59.
} 
the nation state. However, the more fundamental distinction between the citizen and the subject lies in the fact that she is regarded as an individual endowed with rights, liberating the citizen from ties deriving from inherited status. ${ }^{16}$ Accordingly, citizenship and individual rights not only emerged at the same time, but are also co-genital.

Arendt coined the phrase that citizenship consisted of the right to have rights ${ }^{17}$ in order to underline that guaranteeing rights without a reference frame for their enforcement and participative creation ${ }^{18}$ is useless. While this phrase does not answer the question which rights are defining for citizenship, ${ }^{19}$ it highlights that rights are a relational category, thus reminding us of their dialectical character. ${ }^{20}$ Rights presuppose the interaction with fellow humans for their creation as well as for their enforcement - in so far they presuppose society, whether in the form of a constituted political community or some other form. These societies do not have to coincide with nation states - they could even encompass the world. All this demonstrates the centrality of rights for the concept of citizenship. Any contrast between rights and citizenship ${ }^{21}$ is less than convincing if we realise that there can never be any isolated human being as bearer of natural rights. ${ }^{22}$ Rights only make sense in interaction with others.

Social citizenship, thus understood as a specific category of rights is adequate to conceptualise the concern which the constitutional social state pursued: to include not only the citoyen of capitalist societies of the penultimate century, but also a wider and more diverse population, encompassing nonpossessing classes and international migrants. Social citizenship ensures that persons, though formally right-bearing, do not become socially excluded, internally right-less and thus factually, if not legally stateless. ${ }^{23}$ It provides the factual preconditions to enjoy formally endowed rights. Social citizenship is thus inalienable from social rights.

\section{Rights for the many instead of the few: of statuses and two kinds of solidarity}

This leads to the next step in defining social citizenship rights. Social citizenship aims at guaranteeing rights for the many instead of the few. This task requires bridging the tension between enabling individuals to self-govern their lives and the necessity to do justice to the dependence of human beings on each other as well as on the wider animated and inanimate world. Accordingly, rights need to move beyond the liberal paradigm.

\footnotetext{
16 See on this R Bellamy (n.8),

17 H Ahrendt, 'Es gibt nur ein einziges Menschenrecht', Die Wandlung, 4 (1949), 754-70. This is the original German version of the article translated to "The Right of Man: What are they?"

18 R Bellamy, "Right to Have Rights': Citizenship Practice and the Political Constitution of the EU', in R Bellamy, A Warleigh (eds) Citizenship and Governance in the European Union (London: Continuum, 2001), 41-70.

19 This is allured to by D Kochenov, 'The Right to Have What Rights?', (2013) 19 EL, 502.

20 E Balibar, Strangers as Enemies: Further Reflections on the Aporias of Transnational Citizenship (Globalization Working Papers 06/4) (Hamilton: McMaster University, 2006), 13.

21 As made by G Mundlak, 'Industrial Citizenship, Social Citizenship, Corporate Citizenship: I Just Want My Wages', (2007) 8 Theoretical Inquiries in Law, 719, contrasting industrial citizenship with labour rights.

22 M R Somers (n. 14), 7-8,. makes a similar argument, and the same argument can be based on the observation, made by feminist legal theory, that individuals are necessarily embedded in a web of relationships (see S. Moller Okin, 'Equal Citizenship: Gender, Justice and Gender: An unfinished debate', (2004) 72 Fordham Law Review, 1537-67). Another way of expressing this is by reference to autonomy, see for example K Möller, 'Two conceptions of positive liberty: towards an autonomy-based theory of constitutional rights', (2009) 29 Oxford Journal of Legal Studies, 757.

23 This stark terminology allures to M R Somers (n. 14), 24-36.
} 
The liberal paradigm, in a nutshell, relied on the notion of a formal autonomy of the citizen, who was fully capable of governing his own life relying on his (inherited) wealth and the labour of his dependants. His autonomy was only contested by a usurping state, against which liberal citizenship rights were wielded to contest any "intervention". Jellinek, analysing Prussian administrative law, referred to this as the status negativus. ${ }^{24}$ With the inclusion of more and more humans into the citizenry, the liberal notion of formal autonomy was be perceived as unrealistic: as the formally autonomous bourgeois depends on the services of his family and workers, his autonomy needs to be balanced with theirs as soon as they are granted citizenship rights. Social citizenship chimes with Jellinek's status positivus: new groups of citizens, the poor, the workers, the women, cannot factually enjoy citizenship rights in merely defensive mode. They depend on positive rights, as associated with state benefits in regards to provision of housing, education and health care as well as monetary income supplements or minimum wages in order to guarantee subsistence. However, the status positivus is also a status passivus, inevitably entailing some paternalism. By giving those citizens who lack the property-based autonomy characterising the ideal bourgeois citizen state-funded benefits in order to guarantee their capacity to provide for themselves, the difference between bourgeois and the non-possessing classes is entrenched rather than overcome.

Beyond the status positivus, in which citizens are dependent on states, the notion of substantive autonomy requires expanding citizenship rights. What if citizens would not have to rely on state handouts in order to factually enjoy the status of a full citizen? What if they were empowered to fend for themselves? This is the essence of the status socialis activus: ${ }^{25}$ citizens should not only have the right to engage in state-centred public democracy via Jellinek's status activus, but also the right to engage actively in any other sphere where they interact with others. Such spheres will frequently be circumscribed by markets: the housing market, the employment market, the market for bank accounts or the market for education, to name but a few. However, spheres of citizens' interaction can also be nonmarket spheres: the space where those living in a borough interact, the public education system or the participation in the public health service.

Traditionally a status socialis activus is realised in the field of labour relations, frequently referred to as industrial citizenship. ${ }^{26}$ The notion refers to the right of workers to emerge as another group united by a common fate. Combining is the classical term used for this kind of organisation, typically in trade unions, which allows workers to threaten collective action in order to engage their employers in collective bargaining, which again offers them the opportunity to achieve a fair deal on labour markets. ${ }^{27}$

\footnotetext{
24 Georg Jellinek (n. 3) Schiek, (n. 3) 221, and references therein.

25 D Schiek, (n.3), 219-58.

26 T.H. Marshall (n. 6), J Fudge, 'After Industrial Citizenship', (2005) 60 Relations Industrielles / Industrial Relations, 631, G Mundlak (n. 21), P Bagguley, 'Industrial Citizenship: a re-conceptualisation and case study of the UK', (2013) 33 International Journal of Sociology and Social Policy, 265, Ch Zhang, N Lillie, 'Industrial Citizenship, cosmopolitanism and European integration', (2014) 17 European Journal of Social Theory, 1-19.

27 It should be stressed that the assumption that labour markets in particular suffer from an asymmetry is not necessarily based on any Marxist theory. It has famously been explained by the so called fallacy of labour theory, which was developed by economists who were convinced of the market economy in principle. According to this theory, the market for labour suffers from an imbalance, because most workers do not have any alternative to earning their main income on the labour market. Thus, if wages fall below a certain level, workers will not withdraw their labour, but rather expand its supply. For example, they may take on a second occupation, or incite their children to work. This is the basis for an orthodox justification of collective bargaining. While these ideas have been around for a long time (W Stützel, Marktpreis und Menschenwürde [Market Pricing and Human Dignity], 2nd edn (Stuttgart: Bonn Aktuell, 1982), 75-76), they can still be tested in real life scenarios such as the German minimum wage (R Hickel, 'Kritische Hinweise zu P. Kalmbach über
} 
In Marshall's conception industrial citizenship appeared as an afterthought, ${ }^{28}$ since he considered the generation of income independent from the recipients' 'market value' through state benefits as superior. ${ }^{29}$ Collective bargaining as the central element of industrial citizenship by contrast aims to increase the workers' market value through the credible threat of collective action. More recent conceptions of constitutional social state guarantees stress the inherent value of self-determined social participation. In this view, industrial citizenship is a mode for realising self-determination in the market place under conditions of structural inequality. ${ }^{30}$

In the practice of European welfare states, ${ }^{31}$ social citizenship is frequently realised through a mix of benefits and participation. For example, budgets of public social insurances are based on contributions, and frequently administered on the basis of their own democratic governance. Contribution-based benefits on this basis constitute a step towards self-organised social citizenship, pointing back to the origins of some branches of social insurance in employees' self-organisation trough trade unions, which survived in some unemployment insurance systems until recently. ${ }^{32}$ Social insurance thus combines self-organisation typical for the status socialis activus with state benefits typical for the status positivus.

The concept of statuses may seem rather static if used in isolation. Social citizenship in both statuses depends on some emanation of solidarity. However, two different kinds of solidarity underlie the status positivus and the status socialis activus. Overall, it is interaction between human beings and participation in human society which creates and reactivates solidarity. ${ }^{33}$ If social citizenship is the instrument to achieve the inclusion of large partitions of the population into the engagement with their polity, social citizenship also aims at increasing interactions and thus solidarity.

Social citizenship, if based on distribution of payments, also creates interaction between different factions of the citizenry: those who contribute larger parts of the tax base interact with those who receive benefits through the medium of social state. However, this interaction is merely indirect and mediated through the political process. As indicated above, the benefactor (even if it is the state) is the one

Mindestlöhne in Deutschland' (2007) 3 Wirtschaftswoche 696).

28 P Bagguley (n. 26), J Fudge (n. 26).

29 T.H. Marshall (n.6), 42-46, see also 68. There is a link to the more recent concept of the de-commodification effect of the welfare state here Gøsta Esping-Andersen, The Three Worlds of Welfare Capitalism (Cambridge: Polity Press, 1990).

30 M Kittner, D. Schiek, 'Artikel 9 Abs. 3 GG (Koalitionsfreiheit) - Article 9 section 3 German Constitution (Freedom of Association)', in E. Stein, H Denninger, W Hoffmann-Riem (eds) Kommentar zum Grundgesetz - Reihe Alternativkommentare ( (Neuwied: Luchterhand, 2001), marginal number 89-92, with a critique of more limited views.

31 For an overview of European welfare state models involving social insurance see chapters 40-43 in F Castles et al (eds) The Oxford Handbook of the Welfare State, (Oxford: OUP, 2010).

32 Under the so-called "Ghent system", unemployment benefits are linked to an insurance provided by trade unions, as by workers' beneficial societies constituting the fore-runners of trade unions in many European countries in the 20th century. On the history of the system and its longest surviving Scandinavian variety see J Clasen, E Viebrock, 'Voluntary Unemployment Insurance and Trade Union Membership: Investigating Connections in Denmark and Sweden ', (2008) 37 Journal of Social Policy, 433, on more recent developments see Høgedahl, Laust, 'The Ghent effect for whom? Mapping the variations of the Ghent effect across different trade unions in Denmark', (2014) 45 Industrial Relations Journal, 469.

33 This is a Durkheimian concept of solidarity, which constructs solidarity is a type of social relationship. For a short introduction into competing concepts of solidarity in EU integration discourses see M Ross, 'Solidarity - A New Constitutional Paradigm for the EU?', in M. Ross, Y Borgmann-Prebil (eds) Promoting Solidarity in the European Union (Oxford: OUP, 2010), 23, 26-28 with references to classical expositions. 
active here, the passive status of the recipient is not without problems. They receive benefits (preceded by medieval alms), ${ }^{34}$ and are often portrayed as not giving back. Accordingly, it seems appropriate to term this kind of solidarity as 'receptive solidarity'.

The status socialis activus involves more direct engagement of different factions of the citizenry with each other. Beyond relieving citizens from constant worry about their mere existence, the status socialis activus empowers citizens to take political engagement from the narrow realm of the public to the wider realms of the market place and beyond that into civil society. Instead of remaining passive claimants, citizens gain the right to improve their position on markets by direct action - making the benefits potentially superfluous. This leads, of necessity to interaction of those citizens with each other, and of their collective with those multinational corporations, or other people holding private power. Such 'participatory solidarity' may even seem as closer to the meaning of solidarity as interaction. It also expands the realm of the political, thus questioning the neutrality of market forces.

\section{Transnational social citizenship}

If citizenship is conceptualised as a bond between equals joined by 'a shared fate' 35 it is no longer a state-focused notion. People may share the link to the same multinational corporation as their employer, the same housing estate as their landlord or the same higher education sector as employer or the provider of education. These entities may extend beyond national borders or encompass only a fraction of its territory. The society of equals whose fate the citizens share could just as well be the world.

Transnational citizenship ${ }^{36}$ is a term best suited to capture this complex reality. Using the notion "transnational" ${ }^{\prime 37}$ we take into account the continuing relevance of nation states as well as the fact that nation states are increasingly 'relativized' ${ }^{38}$ by transnational interactions. These interactions complete those at national, and also subnational level. Transnational spaces are multi-layered by definition. The dynamic concept of citizenship ${ }^{39}$ offers attractive options here for assessing the emergence of new fate communities as overlapping and pluralist entities. While citizenship is continuously associated

\footnotetext{
34 See B Andersen, 'Precarious Pasts, precarious futures', in Migrants at Work: Immigration and Vulnerability in Labour Law, ed. by Cathryn Costello and Mark Freedland (Oxford: OUP, 2014), 69-84.

35 M R Somers (n. 14).

36 The debate on EU citizenship as transnational citizenship is too voluminous to be referenced in full here. Debates on transnational citizenship commenced in political sociology in the 1990s (e.g. R Bauböck, Transnational Citizenship. membership and rights in international migration (Aldershot: Edward Elgar, 1994), and were expanded to EU critical perspectives around the turn of the century (e.g. Etienne Balibar, We, the People of Europe? Reflections on Transnational Citizenship (Princeton: Princeton University Press, 2004). More recently, legal scholarship also took up the theme (e.g. A. Iliolopoulou Penot, 'The Transnational Character of Union Citizenship', in M Dougan, N Nic Shiubhne, E Spaventa (eds) Empowerment and Disempowerment of the European Citizen, (Oxford: Hart, 2012), 15; R Bellamy, D Castiglione, J Shaw Making European Citizens. Civil Inclusion in a transnational Context, (Basingstoke: Palgrave McMillan, 2006); E D.H. Olsen, Transnational citizenship in the European Union: past, present and future (London: Bloomsbury, 2012); J Lacroix, 'Is Transnational Citizenship (Still) Enough?', in D Kochenov, G de Búrca, A Williams (eds) Europe's Justice Deficit?, (Oxford: Hart, 2015), 177).

37 See also J DeBardeleben, A Hurrelmann, Transnational Europe. Promise, Paradox, Limits (London: Palgrave Mac Millan, 2013).

38 E Balibar (n. 20), 10.

39 Judy Fudge (n. 26), 634.
} 
with specific ties that bind, ${ }^{40}$ individuals can be bound by different ties into different polities, societies and communities.

Just as social citizenship rights which used to be rooted in village, town or guild were transferred to the nation state when industrial capitalism emerged ${ }^{41}$, social citizenship rights can be transferred to transnational entities in order to make them viable for transnational citizenship sites, such as a multinational corporation, a supranational community of states or a regional university. And just as sites of social citizenship within nation states developed in contradictory and diverse forms, sites of social citizenship in transnational entities will evolve in haphazard and possibly even more contradictory ways. Analysing all this is luckily not necessary for a paper focused on rights discourse. ${ }^{42}$ Instead, we can limit our ambition to considering how rights guarantees can negotiate potential tensions between different levels at which social citizenship is enacted and leads to rights.

Intuitively, one would assume that there are differences between rights based on receptive and participative solidarity. This is confirmed by current populist discourse on the extension of benefits beyond national borders as well as on migrants at work.

Relating to the former, restrictions on the poor to move into the catchment area of territorial benefit regimes is much older than the modern welfare state: already in the late middle ages the movement of the poor as well as the distribution of alms (the precursor of benefits) was restricted. ${ }^{43}$ Today, mass media condemn Romanians moving to Northern states where they can claim benefits, ${ }^{44}$ and some governments scold foreigners who partake in national social institutions. ${ }^{45}$ In nested ${ }^{46}$ or semi-sovereign ${ }^{47}$ welfare states, it is alleged that the ties between persons ${ }^{48}$ far away from each other may be too

\footnotetext{
$40 \mathrm{M}$ Wright, T Reeskens, 'Of what cloth are the ties that bind? National identity and support for the welfare state across 29 European Countries', (2013) 20 JEPP, 1443.

41 T.H. Marshall (n. 6), 13.

42 Nor is does a book offer sufficient space to exhaust the theme, see E Balibar (n. 36).

43 From historical perspectives, Anderson exposes how criminalising vagrancy and prohibiting giving alms were used to prevent the poor from moving about (B Andersen, n. 34, 69).

44 For example the German weekly magazine "The Focus" of 11 November 2014 commented on the Court's Dano-ruling [see below] that Germany's generous welfare system would attract some migrants who would only enter Germany in order to claim benefits ("in Deutschland (greift) das Sozialsystem (..) Hilfsbedürftigen finanziell unter die Arme. (...) Das macht die Bundesrepublik auch im Ausland attraktiv: (...) Manche kommen aber auch nur, um Sozialleistungen vom Staat zu kassieren." http://www.focus.de/finanzen/news/arbeitsmarkt/arbeitslosigkeit/harte-regeln-diese-menschen-habenkeinen-anspruch-auf-hartz-iv_id_4266041.html - last visited 23 November 2014).

45 In England, the prime minister has coined the slogan that the National Health Service should not become an International Health Service in response to EU citizenship rights afforded to non UK citizens (A video is still available on the Daily Telegraph web page (http://www.telegraph.co.uk/news/uknews/immigration/9953448/David-Camerons-benefit-tourismpledges-unravel.html, last visited 23 November 2014)

46 M Ferrera, 'Liberal Neo-Welfarism: new perspectives for the European Social Model', Opinion paper: Observatoire social européen, 14 (2013); The Boundaries of Welfare. European Integration and the New Spatial Politics of Social Protection (Oxford: OUP, 2005).

${ }^{47}$ C Bruzelius, E Chase, M Seeleib-Kaiser, Semi-Sovereign Welfare States, Social Rights of EU Migrant Citizens and the Need for Strong State Capacities (Oxford: Oxford Institute of Social Policy, 2014).

48 M Wright, T Reeskens (n. 40)
} 
long to bind reliably. ${ }^{49}$ If there is no "sufficient link", ${ }^{50}$ the payment of benefits to a stranger is perceived as no longer underpinned by feelings of solidarity. If payments to the poor are bound to smaller territorial entities, their actual opportunities to use any free movement rights will be limited. As a result, free movement will be portrayed as the privilege of the better-off, ${ }^{51}$ which again may fuel social envy. All this indicates that a principle of equal treatment for free movers in the receiving society may well be a precondition to make free movement an option for all, but it may also cause resentment in regions with higher welfare state levels, especially if media and politicians link cuts in welfare levels to immigration and free movement.

As regards migrant work, employers may prefer strangers who accept employment for less attractive conditions than the local population, which again stirs xenophobia and rejection of these migrants and their employers. ${ }^{52}$ The strategy of offering very low wages for low qualified and physically demanding work to migrant workers instead of negotiating for locally acceptable wages and conditions confirms the labour market paradox referred to earlier: ${ }^{53}$ employers have more incentive to expand the pool of workers and to create profit margins from low wages than to increase quality of production and to create profit margins from higher turnover. ${ }^{54}$ Transnational movement of labour enhances employers' opportunities to compete through lowering wages, especially in sectors such as the food industry where repetitive and low qualified work can still reap profits. What does this imply for transnational social citizenship?

The fact that migrants are more easily exploited than domestic labour is partly a result of unfamiliarity with local conditions and lower wages at home, ${ }^{55}$ but in other parts it is a function of limited migration rights: migrants who depend on their employer as a residency sponsor have limited options for using positive market effects in their own favour. Equally, if migrants have neither equal rights to social benefits nor to remuneration, the labour market fallacy mentioned earlier works more seriously in the employers' favour. ${ }^{56}$ There is thus an economic argument for awarding migrant workers strong rights to equal treatment in the field of social benefits as well as against their employers.

49 W Lamping, 'Mission Impossible? Limits and Perils of Institutionalising Post-National Social Policy', in M. Ross, Y Borgmann-Prebil (eds) Promoting Solidarity in the European Union (Oxford: OUP, 2010), 46-72.

50 On this aspect of EU citizenship case law see Frank Pennings, 'EU Citizenship: Access to Social Benefits in Other EU Member States', (2012) 28 IJCLLIR, 307.

51 R Bellamy, 'The Liberty of the Postmoderns? Market and Civic Freedom within the EU , 2009. 61 ', LSE Working Paper, 61 (2009); M. Everson, 'A Very Cosmopolitan Citizenship: But Who Pays the Price?', in M Dougan, N Nic Shuibhne, E Spaventa (eds) Empowerment and Disempowerment of the European Citizen, (Oxford: Hart, 2012), 145, St Giubboni, 'European Citizenship and Social Rights in Times of Crisis', (2014) 15 German Law Journal, 935, 944-45; A J Menéndez, 'Which Citizenship? Whose Europe? - The Many Paradoxes of European Citizenship', (2014) 15 German Law Journal, 907.

52 To quote but one contemporary example: a convenience food production chain, after receiving state aid for creating employment opportunities, offered only monotonous and dangerous work instead of more humane conditions to which the local workforce was used. The employer claimed that they had to hire from other EU Member States for these lowwaged posts (http://www.theguardiancom/business/2014/nov/10/sandwich-firm-fill-vacancies-factory-east-europeanworkers )

53 See above text around footnotes 26 to 30 .

54 See, from an orthodox perspective, Martin Ruhs, 'Immigration and Labour Market Protectionism. Protecting Local Workers' Preferential Access to the National Labour Market', in C Costello, M Freedland (eds) Migrants at Work: Immigration and Vulnerability in Labour Law, (Oxford: OUP, 2014), 100, 104-05.

55 S O'Leary, 'Free Movement of Persons and Services', in P Craig, G de Búrca (eds) The Evolution of EU Law, (Oxford: OUP, 2011), 499,506-07.

56 See for a short discussion with ample references M Ruhs (n. 54), 105-07. 
These latter equal treatment rights will only be of use if workers can also enforce them adequately, which again presupposes effective trade union representation for migrants. Transnational labour markets thus demand expanding participatory social citizenship: labour market imbalance calls for a counterweight to employers' advantage. Normatively, it seems more attractive to create this counterweight by participatory solidarity than by receptive solidarity. However, developing such participatory solidarity at transnational levels is fraught with difficulties. The populist argument seems to warrant the exclusion of foreign workers, as in early $20^{\text {th }}$ century guild-type trade union strategies. While the objective situation of low skilled workers may call for international solidarity, there are severe factual barriers for such solidarity, for example in the area of language capacity. For a legal frame of transnational social citizenship all this seems to imply that the law should not create more barriers to the development of transnational participative solidarity than already exist.

This cursory discussion of practical barriers to transnational social citizenship has mainly highlighted difficulties, but also indicated that finding a frame in which factual transnational solidarity can develop is possible in principle. In this regard, equal treatment rights are likely to play an important part, as will the establishment of a constructive interrelation between different sites of social citizenship. Since a full exploration of all this is beyond the scope of any single paper, the remainder of this one will explore two aspects of EU case law on citizenship in order to illuminate the difficulties further.

\section{The EU as a case study for transnational social citizenship}

The EU is considered here as a practical laboratory of transnational (social) citizenship, which is created through a number of mechanisms of this unique polity. While formal EU citizenship plays a role in this endeavour, transnational social spaces as sites of social citizenship emerge from the EU's wider aspirations to create an entity without internal borders. This entity does not only engender interaction between the citizens of the EU member states, but also encompasses immigrants from beyond the EU. The subsequent discussion focuses on the EU Member States' citizens, while highlighting how limited this nationality-focused approach is in reality. The case study is further limited by using the lens of positive law as explicated by ECJ case law. While the frictions of this case law with social reality are highlighted, this is not the space to fully explore them.

\section{EU citizenship, other bases of free movement and equal treatment}

While the EU is exceptional in formally establishing citizenship beyond states, ${ }^{57}$ its positive-legal concept of citizenship is also limited. Since EU citizenship is only granted to nationals of its Member States (Article 9 TEU, Article 20 TFEU), ${ }^{58}$ it is shackled to the nation state.

Such limitations do not necessarily impact on social citizenship. After all, the EU as a transnational space precedes the formal acknowledgement of EU citizenship. This is partly a consequence of the EU's overall concept of integration: in endeavouring to expand a market beyond states, the EU also endeavoured to expand society itself beyond states. ${ }^{59}$ Citizens' interaction is definitely not restricted to some public sphere which would still be controlled by states or the EU as their conglomerate. It mainly occurs on markets. Is citizens' interaction thus necessarily mainly economic or market based in nature? It is

\footnotetext{
57 Peter Kivisto and Thomas Faist, Citizenship. Discourse, Theory and Transnational Prospects (Oxford: Blackwell, 2007), 5, $12,122$.

58 D Kochenov, 'Ius Tractum of Many Faes: European Citizenship and The Difficult Relationship between Status and Rights', (2009) 15 Columbia Journal of European Law, 169-236.

59 This is the main assumption of classical neo-functionalism, for a summary of its approaches see S Saurugger, Theoretical Approaches to European Integration (London: Palgrave McMillan, 2014), 34-53.
} 
unlikely that this is the case. Even in so far as exchange originates from markets, it is fair to state that this does not compromise the societal nature of such exchange. At the very least, market-based exchange leads to more contact between citizens than necessitated for purely economic reasons, making it a good starting point for transnational social space. ${ }^{60}$

Economic free movement rights, in particular free movement of workers, have necessitated rights to receive benefits on the basis of equal treatment in other Member States early on. ${ }^{61}$ The EU's specific model of regional economic integration thus complies with the conditions identified as crucial for transnational social citizenship to survive above. By guaranteeing equal treatment it avoids downward pressure on wages and social benefits to be initiated by migration, which again would create a hotbed for xenophobia, potentially plunging the EU into the abyss from which it was meant to rescue its Member States at the time of its foundation. This explains the inextricable link between free movement of persons and equal treatment in the host state: Since persons are not considered as a commodity which is traded across a border they enjoy the right to equal treatment in their host state. This contrasts with the country of origin principle applied to free movement of products (goods and services) as true commodities, which may well trigger competition between legal orders potentially resulting in a downward spiral of standards. ${ }^{62}$

By contrast, some authors have demanded for immigrant workers to compete against the local population with lower wages. ${ }^{63}$ This cynical proposition conforms to orthodox macroeconomic approaches to global trade and development, which is challenged by heterodox macroeconomic theory. ${ }^{64} \mathrm{This}$ paper does not offer the space to resolve this dispute - but it must be pointed out that off-hand claims to the need of workers to engage in undercutting of wages demanded by unionised workers is economically ill informed. Such strategies may well lead to a general decline in wages, with resulting shrinking of the European economy.

Over time, the EU has developed a contradictory course to equal treatment of its citizens. While it is a continuing principle for economically active EU citizens, the equality rights of non-economically active EU citizens are formally more limited. Free movement of EU citizens is, according to Article 20 TFEU,

\footnotetext{
60 The work of Thomas Risse and Neil Fligstein offer some support for the thesis that citizens who do not interact beyond border develop a limited European identity. Risse, A Community of Europeans? Transnational Identities and Public Spheres (Ithaka N.Y.: Cornell, 2012); Fligstein, Euroclash. The EU, European Identity, and the Future of Europe (Oxford: Oxford University Press, 2008), see also the chapters in G Moro (ed) The Single Currency and European Citizenship: Unveiling the Other Side of the Coin, ed. by Giovanni Moro (New York: Bloomsbury, 2013).

61 This is now regulated by regulation (EU) 492/2011 (replacing regulation (EEC) 1612/68) on the substance of free movement of workers, and regulation EC 883/2004 (replacing regulation (EEC) 1408/71) on the coordination of social security systems, which also covers persons who are self-employed or unemployed. Both are complemented by 2014/54/EU on facilitating the exercise of free movement rights.

62 For a still instructive short introduction see P Davies, 'Posted workers: Single Market or Protection of National Labour Law Systems? ', (1997) 24 CMLR, 571, 585-91.

63 Magnette has famously stated "To equalise the salaries and the social rights of all workers meant depriving migrant workers from their main economic advantage, their lower cost.", referring to granting free movement rights to Italian workers in 1958 as a way to allow Italy "to export its surplus labour" 'How can one be European? Reflections on the pillars of European Identity', (2007) 13 ELJ, 664, 672.

64 It is not possible to provide a full coverage of any of the macroeconomic theories here. An orthodox view on global labour market is presented by R J. Flanagan, Globalization and Labor Conditions (Oxford: OUP, 2006), while J Vercherand, Labour. A Heterodox Approach (London: Palgrave MacMillan, 2014) develops a heterodox analysis.
} 
subject to conditions established by secondary EU law. Secondary EU law has limited those equal treatment rights, which suggests that EU citizenship is but an empty shell. However, the Court of Justice has developed more stringent requirements for Member States to afford the equal treatment rights which are so important for transnational social citizenship, aligning EU citizenship rights with social constitutionalism. ${ }^{65}$ The haphazard and contradictory way in which this case law developed is part of the case study developed more specifically below.

EU law also withholds equal treatment rights from workers through another mechanism. Ever since Southern Enlargement in the 1980s, existing Member States have temporarily restricted free movement of workers of new Member States to avoid that labour markets would become imbalanced. Posting of workers has developed into an alternative route of migration. In the 1990s the Court established the principle that those workers, typically posted to a building site abroad, could not rely on free movement of workers. ${ }^{66}$ Instead their posting is framed as an expression of their employers' freedom to provide services. Any limitations on moving these workers from the employer's country of establishment to the place where their work is needed have been qualified as restrictions of the freedom to provide services. ${ }^{67}$ The ECJ first addressed requirements of immigration control. ${ }^{68}$ However, soon it expired that equal treatment of workers on the same building site would also be conceived as a restriction of freedom to provide services. The Court frequently accepted justifications for those restrictions under the label of workers' rights. ${ }^{69}$ However, the fact remains that workers moving as posted workers cannot claim equal treatment individually, relying on their Treaty rights. Rather the host state may impose on their employer an obligation to grant certain employment rights. While formally workers have a choice whether to move independently or approach an employer who will post them, in practice this choice may be restricted by labour market constraints. There are indications that Eastern enlargement and the long periods for which workers could not rely on individual free movement has entrenched posting as the only way to move into Western labour markets. ${ }^{70}$ Both in relation to economically inactive citizens and to posted workers the EU rescinds the equal treatment guarantee so decisive for social citizenship. EU citizenship rights might thus be of practical use only for the beati possidentes.

\section{Two case studies from the ECJ case law}

Since EU citizenship is to a large extent developed by the EU judiciary, the case law of the Court of Justice conditions the scope of social citizenship - at times expanding and at times restricting it. While judicial governance ${ }^{71}$ is not sufficient to engender EU social citizenship, the Court remains the final arbiter of contestations and conflict. Accordingly, the remainder of this paper focuses on two strands

\footnotetext{
65 On different layers of EU constitutionalism see K Tuori, 'The Many Constitutions of Europe', in K Tuori, S Sankari (eds) The Many Constitutions of Europe (Farnham: Ashgate, 2010), 3; D. Schiek (n. 15), 308.

66 Case C-43/93 Vander Elst [1994] ER I-3803, paragraph 21-22.

67 Case -113/89 Rush Portuguesa [1990] ECR I-1417 paragraph 15.

68 Ibid.

69 The requirement to pay a statutory minimum wage was accepted (C-369/96 Arblade \& Leloup [1999] ECR I-8453, C164/99 Portuguaia Construcões [2002] I-787), as well as demanding social security payments for wage continuation during work stoppage due to winter weather (case C-272/94 Guiot [1996] ECR I-1905) or to secure annual holiday pay (case C490/04 COM v Germany [2007] ECR I-6095) and the requirement to provide surety for workers' wages (case C-60/03 Wolff \& Müller [2004] ECR I-9553).

70 Bertelsmann Stiftung, (2014) Harnessing European Labour Mobility: (Gütersloh: Bertelsmann Stiftung, 2014), $59,74$.

71 On that notion see D Schiek (n. 15), 217-218, 235-237.
} 
of case law and how social citizenship - whether based on receptive or participatory / interactive solidarity - fares before the bars of the EU's highest court.

\section{The ECJ and the status positivus - receptive solidarity}

If there is a field of law in which the ECJ is viewed as a force in favour of the social, this is its citizenship case law. The story of how the ECJ developed the relatively meagre provisions on Union Citizenship in the Treaty of Maastricht into the basic law of multilevel solidarity has been told so often ${ }^{72}$ that short reminders may suffice here. Five years after EU Citizenship had found its way into the Treaties, the Court derived a claim of citizens to equal treatment based on moving to another Member State from what then was Article $12 \mathrm{EC}$ and Article $18 \mathrm{EC}$ [now these are Articles 18 and $20 \mathrm{TFEU}$ ]; ${ }^{73}$ and only three years later it first referred to EU citizenship being a fundamental status. While this phrase has become relevant in cases concerning residence and work permits later on, ${ }^{74}$ it is useful to recall that the phrase was first, in 2001, used in order to require the Member States to extend a certain level of solidarity to student migrants from other Member States. ${ }^{75}$ Another four years later the Court confirmed that this "certain level" was limited indeed, and that Member States could demand a certain degree of integration into the host society before a student could claim equal treatment in regards to benefits designed to facilitate maintaining studies. ${ }^{76}$ This case law was subsequently informed Directive 2004/38/EC. As regards the extent to which "receptive solidarity" is extended to free moving EU citizens and their family, Article 24 of the Directive is the decisive codification. It repeats the principle that EU citizens have a right to equal treatment in relation to social benefits (para 1), but establishes exceptions from that principle: according to paragraph 2, social benefits may be withheld in the first three months of residence, or during such time that the residence of a non-worker is extended for periods of serious job-seeking. In addition, any student benefit can be withheld until the person in question acquires permanent residence. The Court has subsequently specified this case law. The Förster case ${ }^{77}$ established that students may still derive equal treatment rights directly from the Treaty, but that Member States may impose a generalised minimum period of legal residence as proof of sufficient integration. This case law was specific to students, however.

Social rights for citizens less privileged than students constitute more concern for national budgeteers. In this regard, the Court had held in the Trojani case ${ }^{78}$ that Member States may terminate the legal residence of a citizen who became an unreasonable burden on the social assistance system. However,

\footnotetext{
72 The research report by D Kostakopoulou (n. 4) offers a very good overview of this debate.

73 Case C-85/96 Martinez Sala [1998] ECR I-269, confirmed by case C-456/02 Trojani [2004] ECR I-7573

74 The much-discussed Ruiz Zambrano case (C-34/09, ECLI:EU:C:2011:124) concerned not access to social benefits (receptive solidarity) or inclusion in labour unions (participative solidarity), but only residence rights, including a right to a work permit. Residence and free movement was also at stake in the McCarthy cases: one was raised on behalf of an EU citizen and mother caring for disabled children and wishing for her non-EU husband to maintain the family on the basis of a residence permit (C- 434/09 Shirley McCarthy ECLI:EU:C:2011:277; the family background is recalled by N Nic Shuibhne, 'The Kids are alright', (2012) 49 CMLR, 349-379). and on the one was raised on behalf of a comparatively privileged family suffering inconvenience from excessive UK border controls while travelling between their real properties in different Member States (Case C-220/12 Sean Ambrose McCarthy and others ECLI:EU:C:2014:2450).

75 Case C-184/99 Grzelczyk [2001] ECR I-6193

76 Case C-209/03 Bidar [2005] ECR I-219, ruled without direct reference to the Directive.

77 Case C-158/07 Förster [2008] ECR I-8507.

78 Case C-456/02 Trojani ECLI:EU:C:2004:488 (decided on the basis of Directive 90/364/EEC).
} 
it had also confirmed that as long as the residence had not been terminated, the right to equal treatment in relation to social benefits remains intact. ${ }^{79}$ This case law considerably expanded the relevance of EU legal citizenship for promoting transnational movement (and the resulting transnational social space). It clashed with Member States' traditional sovereignty over immigration, and attracted corresponding criticism. ${ }^{80}$ In such a situation the Court tends to contain its own courageous case law and retreat partly. ${ }^{81}$ Accordingly, subsequent case law seemed to confirm that Member States may withhold equal treatment in some instances. ${ }^{82}$ Accepting such an exception from the principle of free movement on the basis of equal treatment would have quite dire consequences indeed. The Member States, instead of complying with the cumbersome procedures of ending the lawful residence of an EU citizen, could just withhold social benefits. They could thus create a social underclass of legally resident EU citizens who nevertheless are excluded from receptive solidarity as part of their social citizenship. These members of an EU Lumpenproletariat would have a strong incentive to sell their (employed or self-employed) labour at any price initially, thus potentially de-valuating the social compromise found in their host state by the level of minimal subsistence granted to all citizens. A relatively recent AG opinion was thus very much to be welcomed. In the Brey case, ${ }^{83} \mathrm{AG}$ Wahl summarised:

96 To resume until a Member State has put an end to the lawful residence of a Union citizen by a decision that complies with the procedural guarantees enshrined notably in articles 15, 30 and 31 of the Directive (...) a citizen (..) may invoke EU law for the duration of his lawful stay. Such a decision must be taken independently from the question whether the Union citizen fulfils the requirement of sufficient resources. ${ }^{84}$

If this statement would have been confirmed in later case law, we could say that the EU had indeed matured into a territory where the minimum requirements of receptive solidarity had acquired a second, transnational level: as long as citizens are legally resident abroad, they can claim the social minimum agreed in their host state. In the Brey case, the Court seemed to follow AG Wahl, though its reasoning was less clear.

The recent Dano ruling, ${ }^{85}$ however, constitutes one of those instances where the Court retreats its steps, and moves backwards. The facts of the case seemed to play on all the fears that populate the European rainbow press: Ms Dano, a Romanian citizen, belonging to the ethnic minority of the Roma, moved from Romania to join her sister in Germany as a teenager and pregnant, and bore a child before her $16^{\text {th }}$ birthday. She never worked, and might find it difficult to access the German employment market due to lack of formal education and ability to write German. The German authorities nevertheless granted her and her son unlimited right to abode in Germany. However, they rejected her application for a specific form of social assistance on the grounds that she was not a worker, and that they could

\footnotetext{
79 Case C-456/02, referenced above, paragraphs 42-43.

80 See above n.74.

81 For an early exploration of this see D Kostakopoulou, 'Ideas, Norms and European Citizenship: Explaining Institutional Change', (2005) 68 Modern Law Review, 23.

82 K Lenaerts, 'European Union Citizenship, National Welfare Systems and Social Solidarity', (2011) 18 Jurisprudencija, 397, referring to cases such as C-158/07 Förster ECLI:EU:C:2008:630, C-162/09 Lassal ECLI:EU:C:2010:592, C-434/09 Shirley McCarthy ECLI:EU:2011:277 and C-325/09 Cias ECLI:EU:2011:498.

83 Case C-140/12 ECLI:EU:C:2013:565

84 Paragraph 96 of the AG Opinion [ECLI:EU:C:2013:337]

85 ECJ C-333/13 Dano, ECLI:EU:C:2014:2358.
} 
refuse to treat her equally with Germans on the grounds of that. On humanitarian grounds, they granted child allowance and a lower level of subsistence benefit, though.

In this case, the Court did not stress that Member States might end the lawful residence of a Union citizen on the grounds that its social assistance system might be overly challenged. Neither did the Court reinforce the right of an EU citizen, as long as they resided lawfully, to be treated equally in relation to social benefits in the host state, except in limited circumstances as specified by secondary law. Guided by AG Wathelet, the Court stressed the dilemmas of the Member State instead: the Member State might find it difficult to fulfil all the requirements demanded by the rule of law in ending the lawful residence of an EU citizen who becomes an undue burden on the public purse. ${ }^{86}$ Accordingly, it allowed Germany to withhold equal access to social assistance without ending Ms Dano's lawful residence. No reference was made to the principle that exceptions to the right to equal treatment enshrined in primary EU Law must be read narrowly. As mentioned, Article 24 of Directive 2004/38 allows withholding equal treatment for finite groups of EU migrants: those who are not economically active within the first three months, those who are students throughout their studies, and those who are jobseekers before they are actually employed. Also, equal treatment may be denied to those who abuse free movement rights. ${ }^{87}$ All other citizens, if they are not able to rely on the economic freedoms, and do not have sufficient means to sustain them, can be expelled once becoming an unreasonable burden on the social system of the host state. After Dano, Member States may withhold equal treatment to any category of citizens who make use of their free movement rights, instead of taking the thorny path of expelling an EU citizen who becomes a burden on their social system.

Politically, this means that the Court has created a social underclass of EU citizens unable to rely on the solidarity extended to the other citizens in the host state. This also erodes social citizenship based on receptive solidarity for those citizens. As Marshall found in the last century, social citizenship allocates income independent from a person's market value - this is the de-commodification function of the welfare state highlighted by Esping-Anderson. ${ }^{88}$ Social citizenship also establishes a level of income below which no citizen has to accept waged or other labour. Introducing an underclass destroys this function of social citizenship also for the nationals of the host state.

The Court has not maintained its stance as a bulwark against nationalist preoccupation with reserving welfare rights to citizens. Sadly, the defence of the national welfare budgets has even been raised by authors who fiercely defend other instances of European social citizenship, such as industrial citizenship. ${ }^{89}$ Once again it has been confirmed that receptive solidarity may be most difficult to expand to EU levels.

\section{The ECJ and the status activus - participatory solidarity}

Does EU level industrial citizenship as an emanation of participative solidarity fare any better before the bars of the ECJ? It is well known that the Court of Justice has issued case law which is widely seen as compromising industrial relations at national levels. The rulings in Laval $^{90}$ and Viking ${ }^{91}$, so widely

\footnotetext{
86 Para. $77-80$

87 Article 35 Directive 2004/38.

88 See above n. 29

89 St Giubboni (n. 51), 942

90 Case C-341/05 [2007] ECR I-11767

91 Case C-438/05 International Transport Workers Federation [2007] ECR I-10779
} 
debated that it is hardly possible to refer to the whole discussion, ${ }^{92}$ constitute the core of the second case study. Both these cases could not have been more different, and shed some light on the difficulties presented by transnational social citizenship based on participatory solidarity.

\section{a) Laval: a national labour market segregated by transnational posting}

In the real life scenario underlying the Laval case, a Swedish trade union engaged in collective action in order to force a Latvian employer to conclude an agreement with them, which would give Latvian workers higher wages that the employer was prepared to pay without such pressure. It is worthwhile explaining the back-ground, since it is not frequently presented in full. Laval, a Latvian company, had won a bid to build a school in North Sweden through their subsidiary Baltic Bygg, a Swedish company. ${ }^{93}$ While it would seem natural for a Swedish company with Latvian roots to hire Latvian workers, they could have allowed Latvian workers to benefit from free movement of workers. After all, Sweden was one of two countries which had opened their labour markets for Eastern European citizens as early as 2004. Baltic Bygg chose a different route: it hired workers from their parent company in Latvia. ${ }^{94}$ This gave them the status of posted workers, whom Laval would treat as Latvians without any right to equal treatment with Swedes, in line with EU legislation on posted workers. ${ }^{95}$

The work on the school started in May 2004, and negotiations with the local trade union on the level of wages to be paid commenced in June. The negotiations collapsed on 15 September $2004,{ }^{96}$ one day after the Latvian employer concluded collective agreements with a trade union representing its workers. It has been stated that "the timing of this agreement suggests an attempt to indulge in a form of 'pre-emptive recognition". ${ }^{97}$ Further, the Latvian workers were not, actually, members of the trade union that negotiated for their wages. Contemporary reports detail a media war between Swedish trade unions trying to attract Latvian workers and Latvian employers assuring that those workers would not find employment in Latvia after joining a Swedish trade union. ${ }^{98}$ As a result, the trade union fought for non-members, and any relations between Latvian and Swedish trade unions has only progressed long after the spectacular case. ${ }^{99}$

\footnotetext{
92 See, for example, C Barnard, S Deakin, 'European Labour Law after Laval ', in M-A Moreau (ed) Before and After the Economic Crisis. What Implications for the European Model? (Cheltenham: Edward Elgar, 2011), 252; B Bercusson, 'Implementing and monitoring of cross-border agreements: the potential role of cross-border collective action', in $\mathrm{K}$ Papadakis (ed) Cross-Border Social Dialogue and Agreements: An emerging global industrial relations framework?, 131; J Malmberg, 'Posting Post Laval. International and National Responses', Uppsala Center for Labor Studies Working Papers, 2010, 1-26; M. Rönnmar, 'Laval Returns to Sweden: The Final Judgment of the Swedish Labour Court and Swedish Legislative Reform', (2010) 39 ILJ; 280, A Supiot, 'Under Eastern Eyes', (2013) 73 New Left Review, 29.

93 Paragraph 27 of the judgment.

94 Paragraph 29 of the judgment

95 Article 1 para 3 Directive 96/71/EC on posting of workers

96 See A Davesne, 'The Laval Case and the Future of Labour Relations in Sweden', (2009) 5 Les Cahiers europeens de Sciences Po, 2009, 6 with ample reference to contemporary newspaper reports.

97 Ch Woolfson, J Sommers, 'European Mobility in Construction', (2006) 12 European Journal of Industrial Relations, 12 , 54.

98 Ibid. p. 55.

99 K Lovén-Seldén, 'Laval and Trade Union Cooperation: Views on the Mobilizing Potential of the Case', (2014) 30 IJLLIR, 87.
} 
The Court focused on the position of the employer, and mainly held that the industrial action went over and above what was necessary to secure adequate employment conditions because the employers would not know before negotiating a collective agreement what actual "tariff" they would be expected to pay their workers. ${ }^{100}$ This position can be criticised as based on ignorance in relation to any bargaining process: it is the nature of negotiations that neither party knows in advance what the result may be. Deriving a right to be subjected to a known tariff only for posted workers from the freedom to provide services, the Court also derived a right not to be subjected to serious collective bargaining, if the employer engages transnationally.

The academic debate ensuing from the Laval case has been criticised as overlooking the interests of Latvian employers and their workers. ${ }^{101}$ However, it might be suggested that both the Latvian workers and the Latvian employers were not much more than extras on the stage in a play enacted by the Swedish employers' associations and their counterparts, the builders' union "Byggnads". While Laval had been active on the Swedish market for construction from 2002, ${ }^{102}$ the Swedish employers' association grasped the opportunity to put a dent in the national system which results in a high wage economy. Accordingly, they continued to fund the litigation even after the claimant had been dissolved due to bankruptcy. ${ }^{103}$ It will never be known whether the Latvian employer gained any advantages from this cooperation, which constitutes a step towards creating transnational social space for industrial relations. Interestingly, the case may have initiated trade union cooperation in the Baltic region as well - similarly dominated by proactivity from the Swedish side. ${ }^{104}$

\section{b) Viking - EU law utilised to destabilise an agreement for international industrial relations}

The Viking case was fundamentally different in that the trade unions representing seafarers had concluded an international agreement regarding their relation to each other. For cases in which an employer would aim to use an employment regime different from that in the country where they held their main assets, trade unions pledged not to start negotiations with that employer, thus securing that the same collective labour agreements would apply after such a virtual move. This would allow the trade unions to exert pressure with the aim to maintain their recognition by that employer, and to continue bargaining with him. They would not have to fear being presented with a collective labour agreement concluded with another trade union, which would change their pressurizing into illegal collective action under a number of national legal regimes. Crucially, the Court found that such an agreement could never be justified, because it had a territorial element. ${ }^{105}$ If this reasoning is maintained in future cases, trade unions would be prevented from exercising one of their core functions - creating pressure to deter employers from avoiding to apply collective agreements to which they are party -

\footnotetext{
100 Paragraph 110 of the judgment

101 D Kukovec, 'Law and the Periphery', European Law Journal, online first (2014), 1, 10. This is not quite accurate, since there is a body of literature based on empirical work in Latvia and Sweden, e.g. A. Davesne (n 96), Ch. Woolfson, J Sommers (n. 97), Ch Woolfson, Ch Thörnqvist, J Sommers, 'The Swedish model and the future of labour standards after Laval', (2010) 41 Industrial Relations Journal, 333.

103 Ch Woolfson, Ch Thörnqvist, J Sommers (n. 101), 341, see also A. Davesne (n 96). It is sometimes suggested that Laval, became insolvent as a result of the collective action. However, since Baltic Bygg was not insolvent, one could also conclude that they allowed their daughter-company Laval to become insolvent as it was no longer needed to challenge an industrial relation system which Baltic Bygg did not appreciate.

104 K Lovén-Seldén (n. 99).

105 Case C-438/05 International Transport Workers Federation [2007] ECR I-10779, paragraph 85
} 
only because the employer makes use of EU economic freedoms to achieve this aim. There is much less industrial relations research into the Viking case, which may be related to the fact that the case was settled in a secret agreement, ${ }^{106}$ and never had any legislative consequences in Finland. ${ }^{107}$

\section{c) Commonality of the cases and relevance for EU level industrial citizenship}

In all their difference, both cases have some issues in common. In both instances, trade unions engaged against labour market segmentations. In the Laval case, the legal frame for the segmentation had been created in the long line of case law on posting, ${ }^{108}$ which established the posted worker as not entitled to equal treatment. In the Viking case, the segmentation of labour aboard a vessel relied on the traditional consequences of "out-flagging", which is just one emanation of employers' practice to move their corporate domicile into a jurisdiction perceived as more favourable without moving their economic activity. ${ }^{109} \mathrm{~A}$ logical counter strategy of trade unions would be to shield processes of negotiating of employment conditions from these exercises in segmentation. The facts of Laval and Viking demonstrate such strategies based on territoriality, and in both cases the Court held that the practice of trade unions to prevent segmentation of labour markets in this way violated EU internal market law unjustifiably.

Reality has progressed beyond Laval and Viking. Sweden has adapted its legislation to satisfy the Court's demands for uniformity (instead of flexibility) in collective agreements. ${ }^{110}$ Also, trade unions have developed more sophisticated internationalisation strategies, ${ }^{111}$ and the European Trade Union congress has even succeeded to convince their counterpart to conclude an EU level agreement for a sector with notoriously low unionisation levels recently. ${ }^{112}$ The facts of the recently decided case Sähköalojen ammttillitto ${ }^{113}$ demonstrate the development: a Finnish trade union had convinced Polish posted workers to join in order to cede claims for payment of posted work to the trade union, which was in an economic position to actually pursue those claims. While AG Wahl was still not comfortable with the fact that Finnish collective agreements apply to posted workers, he conceded that pursuit of workers' wage claims by their trade union would not constitute a restriction of the freedom to provide services. ${ }^{114}$ The Court has ruled accordingly, relying also on Article 47 CFR. While a comprehensive

\footnotetext{
106 Nic Shuibhne. Niamh, 'Settling Dust? Reflections on the Judgments in Viking and Laval', (2010) 21 EJBL, 681, 684.

$107 \mathrm{~N}$ Bruun, Cl-M Jonsson, E Olausen, 'Consequences and Policy Responses in the Nordic Countries as a Result of Certain Decisions of the Court of Justice of the EU', in A. Bücker, W Warnecke (eds) Reconciling Fundamental Rights and Economic Freedoms after Laval, Viking and Rüffert, (Baden-Baden: Nomos, 2011), pp. 19, 22.
}

108 See above text following footnote 66 .

109 A long line of cases has dealt with the move of corporate domiciles for tax reasons into the Netherlands (e.g. case C167/01 Inspire Art [2003] ECRI-10155) or Ireland (e.g. Case C-196/04 Cadbury [2006] ECR I-7995), and accepted in principle the right of business to choose the cheapest legal environment, irrespective from where their activity was actually conducted.

110 M Rönnmar, 'Laval Returns to Sweden: The Final Judgment of the Swedish Labour Court and Swedish Legislative Reform', (2010) 39 ILJ, 280.

111 I Greer, Z Ciupijus, N Lillie, 'The European Migrant Workers Union and the barriers to transnational industrial citizenship', (2013) 19 European Journal of Industrial Relations, 5.

$112 \mathrm{~K}$ Bandas, 'A framework agreement in the hairdressing sector: the European social dialogue at a crossroads', Transfer: European Review of Labour and Research, 2014, on line first.

113 C-396/13, ECLI:EU:C:2015:86,

114 Opinion by AG Wahl of 18 September 2014 (ECLI:EU:C:2014:2236), paragraphs 63-66 on the validity of the Finnish collective bargaining system, paragraphs 40-57 on the question whether the Finnish trade union may represent its Polish 
analysis of this case is beyond this paper, it is worthwhile to highlight the potential of including migrant workers - whether posted or not - into trade unions in the country where they work. This can be considered as an incipient form of European industrial citizenship. Further development can be imagined. For example, trade unions could create framework agreements pledging cooperation in establishing networks of wage contracts. Framework agreements could also establish arrangements on the factual representation of employees with varying or dual places of work. There is no reason, as even the Court of Justice has acknowledged, why trade union members who are posted should not be represented by a trade union in the host state. While EU law has at times viewed those posted workers as unfree labour, not entitled to equal treatment, this reasoning returns some subject status to posted workers. The related opportunity to offer collective representation at the place of work may be used as a starting point to develop a multi-level trade union network capable of countering the disenfranchisement of posted workers in other fields.

The question is, however, whether the frequently demanded respect for national industrial relations models ${ }^{115}$ is all what is needed in order to develop the participative dimension of EU social citizenship. National industrial relations could only be sufficient if collective solidarity, the base of participatory social citizenship, could only derive from reciprocity bonds within national borders. ${ }^{116}$ However, the solidarity bond underlying collective labour relations is based on a different principle, in that it derives from the position in the market-based production of goods and services. Irrespective of territoriality, employees can combine in solidarity in order to overcome employer dominance. The challenge for trade unions is immense, since transnational solidarity in practice demands so much more than language competence - and even this is no small feat. Seriously respecting the access of migrants to labour markets is the higher hurdle for developing common interests of citizens from the EU's different regions.

It has been pointed out that the Laval quartet was issued before the Charter of Fundamental Rights for the European Union became legally binding and that subsequent case law ${ }^{117}$ demonstrates a more acute awareness of the constitutional protection of labour rights. Possibly, the case law of the European Court of Human Rights on the right to collective bargaining will not remain without impact on the EU's highest Court. ${ }^{118}$ The Court would not have to make radical changes to its case law in order to accept industrial citizenship. It would be fully sufficient to view industrial relations and the occasional occurrence of collective industrial action ${ }^{119}$ as a normal element of conducting business in the European Union. Thus, employers would have to expect to be subjected to industrial action once in a while. Experiencing strikes and boycotts would thus not constitute an anomaly, and would not in itself qualify as a restriction of economic freedoms. The court could still intervene if there would be any trade union

members.

115 See for example C Barnard, S Deakin (n. 92).

116 This seems implied by S Giubboni, (n. 51), 951, 959, where he states that the "maintenance of bounded worlds of social justice based on some criterion of territorial belonging" is necessary to maintain any form of social citizenship.

117 COM v Germany C-271/08 [2010] ECR I-7087, see case note by P Syrpis, 'Reconciling Economic Freedoms and Social Rights - The Potential of Commission v Germany (Case C-271/08, Judgment of 15 July 2010)', (2011) 40 ILJ, 222-29.

118 A Veldman, 'The Protection of the Fundamental Right to Strike within the Context of the European Internal Market: Implications of the Forthcoming Accession of the EU to the ECHR', (2013) 9 Utrecht Law Review, 104.

119 On the role of industrial action in securing the effectiveness of EU level collective labour agreements see B Bercusson, (n. 92) and B Hepple, 'The European Right to Strike Revisited', (2013) 140 Giornale di diritto del lavoro e di relatzioni industriali, 575. 
activity merely driven by xenophobic motives. ${ }^{120}$ In this way, the Court would no longer pose a hindrance for developing industrial social citizenship from below.

\section{Conclusion}

Transforming social citizenship in order to adapt to the reality of life in overlapping and multi-layered transnational social spaces is not an easy task. Social citizenship has been read here as a bundle of rights based on two different types of solidarity: receptive solidarity extends to those who cannot fend for themselves, and participative solidarity allows to structure more efficiently but also more justly markets characterised by paradoxical imbalances. The archetypical form of social citizenship based on receptive solidarity consists of benefits from the public purse; the archetypical form of social citizenship based on participative solidarity is the combination of workers in trade unions.

As a transnational concept, social citizenship based on receptive solidarity attains a dual function. On the one hand, the transnational free mover is in need of protection against being discriminated by the social provider in the host region. An equal treatment principle will also prevent that migrants need to take recourse to undercutting social minimum standards in a merciless competition which is very unlikely to lead to any race to the top. This also protects the position of the resident population from the emergence of a migrant population ready to accept any work or self-employed occupation for any price, because they are excluded from the social civilisation minimum developed for the relevant host society. Nevertheless, receptive social solidarity will meet budgetary limits in some circumstances, which creates support for residual supranational social benefits, ${ }^{121}$ or at least for compensation fund arrangements counteracting sustained imbalances of burdens.

Social citizenship based on participative solidarity is more open to adaptation to transnational spaces because it relies on factual interaction in transnational settings such as markets or other social fields. The actual opportunity to combine with those in a similar position in order to enhance one's fate is the key to this type of social citizenship. However, participative solidarity depends on actual interaction. If and when language barriers can be overcome, the divergence of micro interests within categories such as workers (whether employed or self-employed) increases with dimensions of trans-nationality. Finding a common interest sufficiently compelling to combine might be difficult, and solidarity relations take time to build. In this situation, multi-level legal orders, including their courts, must refrain from restricting emergence of transnational solidarity is not hindered by the legal system.

Despite all its uniqueness in providing for formal citizenship beyond nation states, it is not surprising that the EU does not yet provide an adequate frame for transnational social citizenship. Politically, it is hindered by current trends within Member States to reclaim national social policy competences. Constitutionally, its greatest strength lies in the numerous guarantees of equal treatment for free moving citizens. However, these constitutional guarantees are not consistent. Not economically active citizens and posted workers are deprived from their equal treatment rights. The EU judiciary has also played a contradictory role. In the field of social benefits, it has promoted rights to equal treatment beyond restrictive secondary law at times. However, this case law was never consistent, and the recent Dano ruling indicates that the Court accepts the Member States' competence to exclude citizens from

\footnotetext{
120 More detail see D Schiek (n. 15), 240-43.

121 For the social citizenship models on the other side of the Atlantic, which rely on US or Canadian federal budgets for considerable proportions of "redistributive" welfare payments see K. Lenaerts (n. 82), 400-02 and A Verdun, D Wood, 'Governing the social dimension in Canadian federalism and European Integration ', (2013) 56 Canadian Public Administration, 173-84.
} 
the community of equals on their territory. As regards participative solidarity through trade unions, the Court has prioritised free movement rights of employers in its Laval and Viking case law, without considering the complex situation of free moving workers, whether posted or employed in a mobile trade such as transports. Ironically, the Court's case law has engendered transnational cooperation not only of employers' associations, but also of trade unions. It may thus have helped to overcome demands that industrial citizenship should remain national. However, the Court has a long way to go to find sustainable answers to the challenges of transnational social citizenship.

\section{Table of Contents}

\section{A. Introduction}

\section{B. Towards transnational social citizenship}

I. The social citizenship metaphor

II. Rights in constitutional welfare states

III. Rights and social citizenship

IV. Rights for the many instead of the few: of statuses and two kinds of solidarity

V. Transnational social citizenship

\section{The EU as a case study for transnational social citizenship}

I. EU citizenship, other bases of free movement and equal treatment

II. Two case studies from the ECJ case law

1. The ECJ and the status positivus - receptive solidarity

2. The ECJ and the status activus - participatory solidarity

a) Laval: a national labour market segregated by transnational posting

b) Viking - EU law utilised to destabilise an agreement for international industrial relations 17

c) Commonality of the cases and relevance for EU level industrial citizenship 


\section{Bibliography}

Ahrendt, H., 1949. Es gibt nur ein einziges Menschenrecht. Die Wandlung, 4(3), pp. 754770.

Andersen, B., 2014. Precarious Pasts, precarious futures. In: C. Costello \& M. Freedland, Hrsg. Migrants at Work: Immigration and Vulnerability in Labour Law. Oxford: Oxford University Press, pp. 69-84.

Bagguley, P., 2013. Industrial Citizenship: a re-conceptualisation and case study of the UK. International Journal of Sociology and Social Policy, 33(5/6), pp. 265-279.

Balibar, E., 2004. We, the People of Europe? Reflections on Transnational Citizenship. Princeton: Princeton University Press.

Balibar, E., 2006. Strangers as Enemies: Further Reflections on the Aporias of Transnational Citizenship (Globalization Working Papers 06/4). Hamilton: McMaster University.

Bandas, K., 2014. A framework agreement in the hairdressing sector: the European social dialogue at a crossroads. Transfer: European Review of Labour and Research, p. on line first.

Barnard, C. \& Deakin, S., 2011. European Labour Law after Laval . In: M. Moreau, Hrsg. Before and After the Economic Crisis. What Implications for the European Model?. Cheltenham: Edward Elgar, pp. 252-269.

Bauböck, R., 1994. Transnational Citizenship. membership and rights in international migration. Aldershot: Edward Elgar.

Bellamy, R., 2001. 'Right to Have Rights': Citizenship Practice and the Political Constitution of the EU. In: R. Bellamy \& A. Warleigh, Hrsg. Citizenship and Governance in the European Union. London: Continuum, pp. 41-70.

Bellamy, R., 2009. The Liberty of the Postmoderns? Market and Civic Freedom within the EU , 2009. 61. LSE Working Paper, 61(1), pp. 1-38.

Bellamy, R., 2014. Citizenship: Historical Development of. In: J. Wright, Hrsg. International Encyclopaedia of Social and Behavioural Sciences. 2nd Hrsg. s.I.:Elsevier.

Bellamy, R., Castiglione, D. \& Shaw, J. Hrsg., 2006. Making European Citizens. Civil Inclusion in a transnational Context. Basingstoke: Palgrave McMillan.

Bercusson, B., 2008. Implementing and monitoring of cross-border agreements: the potential role of cross-border collective action. In: K. Papadakis, Hrsg. Cross-Border Social Dialogue and Agreements: An emerging global industrial relations framework?. Geneva: International Labour Organization, pp. 131-157.

Bercusson, B., 2009. European Labour Law. 2 Hrsg. Cambridge: Cambridge University Press.

Bertelsmann Stiftung, 2014. (2014) Harnessing European Labour Mobility. Gütersloh: Bertelsmann Stiftung.

Bruun, N., Jonsson, C.-M. \& Olausen, E., 2011. Consequences and Policy Responses in the Nordic Countries as a Result of Certain Decisions of the Court of Justice of the EU. In: A. Bücker \& W. Warnecke, Hrsg. Reconciling Fundamental Rights and Economic Freedoms after Laval, Viking and Rüffert. Baden-Baden: Nomos, pp. 19-44. 
Bruzelius, C., Chase, E. \& Seeleib-Kaiser, M., 2014. Semi-Sovereign Welfare States, Social Rights of EU Migrant Citizens and the Need for Strong State Capacities. Oxford: Oxford Institute of Social Policy.

Búrca, G. d., 2001. Report on the Further Development of Citizenship in the European Union. Zeitschrift fur Sozialreform , pp. 39-63.

Castles, F. et al. Hrsg., 2010. The Oxford Handbook of the Welfare State. Oxford: Oxford University Press.

Clasen, J. \& Viebrock, E., 2008. Voluntary Unemployment Insurance and Trade Union Membership: Investigating Connections in Denmark and Sweden. Journal of Social Policy, 37(3), pp. 433-452.

Davesne, A., 2009. The Laval Case and the Future of Labour Relations in Sweden. Les Cahiers europeens de Sciences Po, p. 5.

Davies, P., 1997. Posted workers: Single Market or Protection of National Labour Law Systems?. Common Market Law Review, 24(4), pp. 571-602.

DeBardeleben, J. \& Hurrelmann, A., 2013. Transnational Europe. Promise, Paradox, Limits. London: Palgrave MacMillan.

Esping-Andersen, G., 1990. The Three Worlds of Welfare Capitalism. Cambridge: Polity Press.

Everson, M., 2012. A Very Cosmopolitan Citizenship: But Who Pays the Price?. In: Empowerment and Disempowerment of the European Citizen. Oxford: Hart, pp. 145167.

Faist, T., 2001. Social Citizenship in the European Union: nested membership. Journal of Common Market Studies, 39(1), pp. 37-58.

Ferrera, M., 2005. The Boundaries of Welfare. European Integration and the New Spatial Politics of Social Protection. Oxford: Oxford University Press.

Flanagan, R. J., 2006. Globalization and Labor Conditions. Oxford: Oxford University Press.

Fligstein, N., 2008. Euroclash. The EU, European Identity, and the Future of Europe. Oxford: Oxford University Press.

Fudge, J., 2004. After Industrial Citizenship. Relations Industrielles / Industrial Relations, 60(2), pp. 631-657.

Giubboni, S., 2014. European Citizenship and Social Rights in Times of Crisis. German Law Journal, 15(5), pp. 935-963.

Greer, I., Ciupijus, Z. \& Lillie, N., 2013. The European Migrant Workers Union and the barriers to transnational industrial citizenship. European Journal of Industrial Relations, 19(1), pp. 5-20.

Hepple, B., 2013. The European Right to Strike Revisited. Giornale di diritto del lavoro e di relatzioni industriali, 140(4), pp. 575-584.

Hickel, R., 2007. Kritische Hinweise zu P. Kalmbach über Mindestlöhne in Deutschland. Wirtschaftsdienst, 3(10), pp. 696-698.

Høgedahl \& Laust, 2014. The Ghent effect for whom? Mapping the variations of the Ghent effect across different trade unions in Denmark. Industrial Relations Journal, 45(6), p. 469-485. 
Hurrelmann, A., 2015. Demoi-cratic Citizenship in Europe - an impossible ideal?. Journal for European Public Policy, 22(1), pp. 19-36.

Iliolopoulou Penot \& Anastasia, 2012. The Transnational Character of Union Citizenship. In: M. Dougan, N. N. Shiubhne \& E. Spaventa, Hrsg. Empowerment and Disempowerment of the European Citizen. Oxford: Hart Publishing, pp. 15-36.

Jellinek, G., 1892. System der subjektiven öffentlichen Rechte. Freiburg i. Br: Akademische Verlagsbuchhandlung Mohr.

Katrougalos, G. S., 2007. The (Dim) Perspectives of the European Social Citizenship. Jean Monnet Working Papers New York University School of Law, 5(1), pp. 1-52.

Kittner, M. \& Schiek, D., 2001. Artikel 9 Abs. 3 GG (Koalitionsfreiheit) - Article 9 section 3 German Constitution (Freedom of Association). In: E. Denninger, W. Hoffmann-Rim, H. Schneider \& E. Stein, Hrsg. Kommentar zum Grundgesetz - Reihe Alternativkommentare (Commentary to the German Constitution - series critical commentaries). Neuwied: Luchterhand, pp. 1-99.

Kivisto, P. \& Faist, T., 2007. Citizenship. Discourse, Theory and Transnational Prospects. Oxford: Blackwell Publishing.

Kochenov, D., 2009. IUS TRACTUM of Many Faes: European Citizenship and The Difficult Relationship Between Status and Rights. Columbia Journal of European Law, 15(1), pp. 169-236.

Kochenov, D., 2013. The Right to Have What Rights?. European Law Journal, 19(3), pp. 502516.

Kostakopoulou, D., 2005. Ideas, Norms and European Citizenship: Explaining Institutional Change. Modern Law Review, 68(2), pp. 233-267.

Kostakopoulou, D., 2013. Co-Creating European Union Citizenship: A Policy Review. Brussels: European Commission.

Kukovec, D., 2014. Law and the Periphery. European Law Journal, Band online first, pp. 123.

Lacroix, J., 2015. Is Transnational Citizenship (Still) Enough?. In: D. Kochenov, G. d. Búrca \& A. Williams, Hrsg. Europe's Justice Deficit. Oxford: Hart Publishing, pp. 177-191.

Lamping, W., 2010. Mission Impossible? Limits and Perils of Institutionalising Post-National Social Policy. In: Promoting Solidarity in the European Union. Oxford: OUP, pp. 4672.

Lenaerts, K., 2011. European Union Citizenship, National Welfare Systems and Social Solidarity. Jurisprudencija, 18(2), pp. 397-422.

Lovén-Seldén, K., 2014. Laval and Trade Union Cooperation: Views on the Mobilizing Potential of the Case. International Journal on Comparative Labour Law and Industrial Relations, 30(1), pp. 87-104.

Magnette, P., 2007. How can one be European? Reflections on the pillars of European Identity. European Law Journal, Band 13, pp. 664-679.

Magnusson, L. \& Stråth, B. Hrsg., 2004. A European Social Citizenship?: Preconditions for Future Policies from a Historical Perspective. Brussels: Peter Lang.

Malmberg, J., 2010. Posting Post Laval. International and National Responses. Uppsala Center for Labor Studies Working Papers, Issue 5, pp. 1-26. 
Marshall, T., 1950. Citizenship and Social Class. Cambridge: Cambridge University Press.

Menéndez, A. J., 2014. Which Citizenship? Whose Europe? - The Many Paradoxes of European Citizenship. German Law Journal, 15(5), pp. 907-934.

Moller Okin, S., 2004. Equal Citizenship: Gender, Justice and Gender: An unfinished debate. Fordham Law Review, 72(3), pp. 1537-1567.

Möller, K., 2009. Two conceptions of positive liberty: towards an autonomy-based theory of constitutional rights. Oxford Journal of Legal Studies, 29(4), pp. 757-786.

Mundlak, G., 2007. Industrial Citizenship, Social Citizenship, Corporate Citizenship: I Just Want My Wages. Theoretical Inquiries in Law, 8(2), pp. 719-748.

Nic Shuibhne, N., 2010. Settling Dust? Reflections on the Judgments in Viking and Laval. European Journal of Business Law, 21(5), pp. 681-703.

Nic Shuibhne, N., 2012. The Kids are alright. Common Market Law Review, 49(2), pp. 349379 .

O'Leary, S., 2011. Free Movement of Persons and Services. In: P. Craig \& G. de Búrca, Hrsg. The Evolution of EU Law. Oxford: Oxford University Press, pp. 499-545.

Olsen, E. D., 2012. Transnational citizenship in the European Union: past, present and future. London: Bloomsbury.

Pennings, F., 2012. EU Citizenship: Access to Social Benefits in Other EU Member States. International Journal of Comparative Labour Law and Industrial Relations, 28(3), pp. 307-334.

Risse, T., 2012. A Community of Europeans? Transnational Identities and Public Spheres. Ithaka N.Y.: Cornell.

Rönnmar, M., 2010. Laval Returns to Sweden: The Final Judgment of the Swedish Labour Court and Swedish Legislative Reform. Industrial Law Journal, 39(1), pp. 280-298.

Ross, M., 2010. Solidarity - A New Constitutional Paradigm for the EU?. In: Promoting Solidarity in the European Union . Oxford: OUP, pp. 23-45.

Ruhs, M., 2014. Immigration and Labour Market Protectionism. Protecting Local Workers' Preferential Access to the National Labour Market. In: C. Costello \& M. Freedland, Hrsg. Migrants at Work: Immigration and Vulnerability in Labour Law. Oxford: Oxford University Press, pp. 100-118.

Saurugger, S., 2014. Theoretical Approaches to European Integration. London: Palgrave McMillan.

Schiek, D., 2001. Artikel 20 Abs. 1-3 V: Sozialstaat. In: Alternativkommentar zum Grundgesetz. Neuwied et al: Luchterhand.

Schiek, D., 2012. Fundamental Rights Jurisprudence between Member States' Prerogatives and Citizens' Autonomy. In: H. Mickitz \& B. De Witte, Hrsg. The European Court of Justice and the Autonomy of Member States. Antwerp: Intersentia, pp. 219-258.

Schiek, D., 2012. Economic and Social Integration. The Challenge for EU Constitutional Law. Cheltenham: Edward Elgar.

Schmitter, P. \& Bauer, M. W., 2001. A (Modest) Proposal for Expanding Social Citizenship in the EU. Journal of European Social Policy, 11(1), pp. 55-65. 
Shaw, J., 1998. The Interpretation of European Union Citizenship. Modern Law Review, 61(3), pp. 293-317.

Somers, M. R., 2008. Genealogies of Citizenship: Markets, Statelessness, and the Right to Have Rights. Cambridge: Cambridge University Press.

Stützel, W., 1982. Marktpreis und Menschenwürde [Market Pricing and Human Dignity]. 2nd Hrsg. Stuttgart: Bonn Aktuell.

Taylor-Gooby, P., 2008. Reframing Social Citizenship. Oxford : Oxford University Press.

Tuori, K., 2010. The Many Constitutions of Europe. In: K. Tuori \& S. Sankari, Hrsg. The Many Constitutions of Europe. Farnham: Ashgate, pp. 3-30.

Veldman, A., 2013. The Protection of the Fundamental Right to Strike within the Context of the European Internal Market: Implications of the Forthcoming Accession of the EU to the ECHR. Utrecht Law Review, 9(1), pp. 104-117.

Vercherand, J., 2014. Labour. A Heterodox Approach. London: Palgrave MacMillan.

Verdun, A. \& Wood, D., 2013. Governing the social dimension in Canadian federalism and European Integration. Canadian Public Administration, 56(2), pp. 173-184.

Woolfson, C. \& Sommers, J., 2006. European Mobility in Construction. European Journal of Industrial Relations, 12(1), pp. 12-68.

Woolfson, C., Thörnqvist, C. \& Sommers, J., 2010. The Swedish model and the future of labour standards after Laval. Industrial Relations Journal, 41(4), pp. 333-350.

Wright, M. \& Reeskens, T., 2013. Of what cloth are the ties that bind? National identity and support for the welfare state across 29 European Countries. Journal of European Public Policy, 20(10), pp. 1443-1463.

Zhang, C. \& Lillie, N., 2014. Industrial Citizenship, Cosmopolitanism and European Integration. European Journal of Social Theory, pp. 1-19. 